\title{
The influence of taxes on migration: evidence from Switzerland
}

\author{
Thomas Liebig and Alfonso Sousa-Poza ${ }^{\star}$
}

\begin{abstract}
Empirical studies on the impact of taxation on migration have been limited by a lack of comparable data in an international context and a lack of variation in tax burdens within countries. A notable exception to the latter is Switzerland. Prior empirical studies on tax competition in Switzerland have had to rely on aggregated data. In general, these studies have been supportive of the notion of tax competition, i.e., high earners tend to relocate to low-tax regions. The authors use an alternative panel approach based on micro-data from the first three waves of the newly established Swiss Household Panel. Despite active community tax policies aimed at attracting new residents and a significant increase in tax-burden dispersion among communities in the past decade, no tax-induced migration is observed. Migration decisions are found to be strongly influenced by accommodation-related factors that point to important housing-market effects.
\end{abstract}

Key words: Migration, Tax competition, Switzerland

FEL classifications: $\mathrm{H} 2, \mathrm{H} 7, \mathrm{~J} 6, \mathrm{R} 23$

\section{Introduction}

Although the impact of income tax competition on migration has-since the seminal contribution of Tiebout (1956) - been extensively discussed in the literature, it has only recently emerged on the agenda of policy-makers, particularly in the European Union. At the same time, various OECD countries, including Germany, are discussing more tax autonomy for local governments (see OECD, 1999A). The main argument is greater efficiency, i.e., that local governments can adapt better to the preferences and needs of their respective constituencies. In addition, from a political-economy perspective, fiscal decentralisation may limit government growth by preventing excessive taxation and increasing government accountability. In contrast, local governments may engage in

Manuscript received 3 May 2004; final version received 24 September 2004.

Address for correspondence: Thomas Liebig, Research Institute for Labour Economics and Labour Law, Guisanstrasse 92, CH-9010 St. Gallen, Switzerland; email: Thomas.Liebig@unisg.ch

* Department of Economics and Research Institute for Labour Economics and Labour Law, University of St Gallen. We should like to thank Isabelle Joumard, Christoph Schaltegger, Kurt Schmidheiny and Rainer Winkelmann for valuable comments and Leonhard Becker for excellent research assistance. This paper was presented at the Annual Meeting of the Swiss Society of Economics and Statistics, 18-19 March 2004 (Basle); the Annual Conference of the European Society for Population Economics, 10-12 June 2004 (Bergen) and the 16th Annual Meeting on Socio-Economics, 8-11 July (Washington, D.C.). Parts of the paper are included in a research project which Thomas Liebig has conducted as a consultant for the OECD's International Migration Division. Financial assistance from the Swiss National Science Foundation (grant no. 5004-69464) is gratefully acknowledged. Thomas Liebig would also like to thank the German National Merit Foundation's PhD scholarship programme for financial support.

(C) The Author 2005. Published by Oxford University Press on behalf of the Cambridge Political Economy Society. All rights reserved. 
wasteful competition for taxpayers, which could also distort migration decisions. With the ongoing integration of the European Union and decreasing migration costs, the discussion has gained further impetus and has been placed on the international political agenda. Indeed, there are many similarities between fiscal relations across the European Union and within an individual country (Joumard and Konsgrud, 2003, p. 20). Accordingly, research efforts aimed at the interaction between migration and taxation have intensified, and tax competition through personal income tax have become a major concern among policy-makers.

Despite numerous theoretical contributions, empirical studies on the effect of taxation on migration are still very rare. This scarcity applies especially to studies based on microdata. Such a deficiency can be attributed primarily to two phenomena. First, even though tax considerations influence the net return on migration, they are not the sole determinants of migration. ${ }^{1}$ Therefore, they cannot be easily isolated from other factors which also determine the net return such as wages, local amenities, housing prices and migration costs. In addition, these factors intervene with 'locational' preferences and subjective evaluations. Second, labour is neither as homogeneous nor as mobile as capital. Moreover, host countries place restrictions on the immigration of labour, which makes studies on the impact of tax considerations largely infeasible in an international context.

In principle, one could also study the internal migration of individuals within the European Union, especially as nationals from EU countries enjoy freedom of movement throughout the Union and tax rates vary widely. Nevertheless, to date, empirical studies on tax competition in the European Union have concentrated on capital tax competitionwhich is fundamentally different from income tax competition, inter alia because mobility costs are considerably lower and preferences do not play a role. Altshuler and Goodspeed (2002) estimate reaction functions between EU countries in a Nash competition model. While they find evidence for a strategic setting of capital taxation, they find no support for strategic interaction with respect to the tax burden on labour. This finding is not surprising as, within the European Union, structural and institutional differences between countries are generally too large to allow isolation of the impact of a particular factor like taxation on migration, particularly if based on aggregated data.

One way of overcoming the above-mentioned obstacles is to focus on internal migration in countries that have a decentralised tax structure. However, only a few countries have such a structure. Among these, Switzerland stands out as the nation with the largest variation in tax rates at the sub-central level. In the US, which also has a decentralised tax structure, less than $10 \%$ of local communities levy income taxes, and the rates are generally low (see Wallace and Edwards, 1999). Therefore, some of the most prominent empirical studies on tax competition are based on Swiss data, including the contributions of Feld and Kirchgässner (2001) and Kirchgässner and Pommerehne (1996). Yet it should be noted that these studies are based on aggregated data. Clearly, then, an analysis using micro-data is desirable, as it allows for the control of the individual characteristics that determine the migration decision and avoids the endogeneity problems inherent in aggregated data in the context of tax competition. Such an empirical study using micro-data is now possible because of the newly established Swiss Household Panel.

The aim of this paper is to analyse the impact of the tax burden on migration in the Swiss context. In contrast to earlier studies, we are not only able to conduct an analysis based on

\footnotetext{
${ }^{1}$ According to the human capital theory of migration, which was introduced by Sjastaad (1962), the migration decision is determined by its net discounted return. For an overview of migration models, see e.g., Massey et al. (1993).
} 
micro-data but also to cover the whole of Switzerland. As Switzerland is the OECD country with the largest variation in income tax rates across local communities, we are able to fill an important gap in the growing empirical literature on the impact of taxes on migration. Prior empirical studies from other countries have been largely inconclusive, not surprisingly given that local communities in other countries do not have much income tax autonomy. Thus, these studies have had to rely on other fiscal parameters such as welfare payments and property taxes. In contrast, we have a direct measure of the tax burden and are therefore able to analyse its effect on migration directly.

The paper is structured as follows. Section 2 outlines the theoretical background for the ensuing analysis. Section 3 briefly sketches selected prior literature on migration and tax competition, with particular reference to the Swiss case. Section 4 then summarises some important particularities of the Swiss tax system. Section 5 presents the data and methodology of the empirical analysis the results of which are then discussed in Section 6. Section 7 concludes the paper.

\section{Theoretical considerations}

The impact of tax rates on an individual's migration decision is relatively straightforward. For John Hicks (1932, p. 76), the incentives for migration were clear: '[D]ifferences in net economic advantages, chiefly differences in wages, are the main causes of migration.' This concept of differences in net economic advantages, which became the starting point for the traditional economic migration literature, has since been formalised by Todaro (1969) and Harris and Todaro (1970). In a setting with multiple prospective destinations, migration takes place into country $j$ in which the net expected income stream $V_{j}(0)$ is maximised $(j=$ 0 for the country of origin and $j=1,2$, etc. for the prospective destinations): ${ }^{1}$

$$
j \in \arg \max _{j} V_{j}(0)=\int_{t=0}^{n}\left[p_{j}(t)\left(1-\tau_{j}\right) Y_{j}(t)\right] \mathrm{e}^{-r t} \mathrm{~d} t-\left\{0 \text { for } j=0 ; C_{j}(0) \text { otherwise }\right\}
$$

where $V(0)$ is the expected discounted net present value of the income gain from migration over the time horizon $n, r$ is the discount rate, $C(0)$ represents the migration costs, $Y(t)$ are wages at time $t, \tau$ is the respective effective tax rate and $p_{j}(t)$ is the probability of being employed.

The hypothesis is straightforward: Persons with a higher income also pay more taxes for given rates and face a higher tax burden. People with a high tax burden should, ceteris paribus, be more inclined to migrate for fiscal reasons.

However, it is likely that the entire family rather than the individual is the relevant decision-making unit. Mincer (1978) used the concept of family ties to explain migration propensities of families vis-à-vis individuals, concluding that these attachments deter migration, particularly in the presence of working spouses. We should therefore observe a negative correlation between family (household) size and the migration inclination. Moreover, a migration decision that is optimal for the entire family is not necessarily optimal for each individual. In terms of formula (1a), the original $V_{j}(0)$ now becomes

\footnotetext{
${ }^{1}$ In addition, net wages should be adjusted for purchasing power by multiplying the net terms by some purchasing power measurement.
} 
a sum of $V_{i j}(0)$, with $i=1,2, \ldots$, representing the various family members. The new maximisation problem for a family $f$ of size $m$ is therefore

$$
j \in \arg \max _{j} V_{j}(0)=\arg \max _{j} \sum_{i=1}^{m} V_{i j} \equiv V_{f}(0)
$$

The net family income, however, has to be adjusted for location-specific utility, which is derived from the consumption of generally available goods on the one hand and from tangible and intangible location-specific goods and services such as proximity to relatives, area amenities, climate, security and quality of life on the other. A household's utility can thus be represented by a utility function $U$ of the following form (Wallace et al., 1997, 40ff)

$$
U=U\left(X_{1}, X_{2}, \ldots, X_{k} ; Z_{k+1}, Z_{k+2}, \ldots, Z_{k+l}\right),
$$

where $X_{a}(a=1,2, \ldots, k)$ denotes the goods and services that can be consumed independently from a specific location. $Z_{b}(b=k+1, k+2, \ldots, k+1)$ depicts locationspecific goods (i.e., not all the $Z_{b}$ are available at every locality) for each location $j$, and only the available goods are included. The household's (static) choice is thus constrained by location-specific budget functions, expressed as follows

$$
Y_{j}=\sum_{a=1}^{k} v_{a} X_{a}+\sum_{b=k+1}^{k+l} v_{b} Z_{b}
$$

where $v_{a}, v_{b}$ are the prices of the respective goods and services.

Equation (3) can also be interpreted as the point of departure for the literature on tax competition. Tiebout (1956) argued that competing local governments offer different tax and expenditure packages. ${ }^{1}$ If people are sufficiently mobile, they migrate to the community with the tax/expenditure package that corresponds to their preferences. In equilibrium, an efficient allocation of resources emerges-no individual can improve his or her utility by moving to another community. A Tiebout equilibrium without migration only arises if taxes are used to finance public goods and are not aimed at redistributing income (see also Hansen and Kessler, 2001). ${ }^{2}$ Furthermore, the Tiebout model should only apply to an agglomeration area, as it ignores the fact that most jobs are bound to a specific workplace. For a given job, a Tiebout-type migration should only occur within a distance in which commuting is possible (see Mieszowski and Zodrow, 1989). Notwithstanding these restrictions, the resulting Tiebout equilibrium is consistent with jurisdictions that have different tax schemes, i.e., differing tax rates may reflect varying demands for certain public goods. ${ }^{3}$ Furthermore, Oates (1969) has argued that differences in taxes and local public goods should be capitalised in the community's property values. If changes in the community tax burden were instantaneously capitalised, this would inhibit tax-induced migration. However, there are both theoretical and empirical arguments for a less-than-full capitalisation of fiscal differences in housing and property values, particularly regarding income taxes (see Feld, 2000, for an overview). More important, capitalisation should have different effects on different population groups, because income tax capitalisation does not depend on the respective household income, and preferences for housing size may differ among households. We might then observe migration due to housing effects but not taxation.

\footnotetext{
${ }^{1}$ The original model was non-formal but has received formalisation and adaptation in the work of Oates (1972) and others. An overview of the Tiebout literature is provided in Dowding and John (1994).

${ }^{2}$ Of course, if redistribution is part of an individual's utility function, (some) redistribution does not prevent a Tiebout equilibrium without fiscally induced migration.

${ }^{3}$ In general, the Tiebout literature emphasises the favourable aspects of fiscal federalism, whereas the tax competition literature (in the more stringent sense) focuses on the distortionary effects of different tax rates on the efficiency of allocation (see Brueckner, 2004, for a comparison).
} 
In a Tiebout setting, migration occurs under only two circumstances: either the individual's preference structure changes (e.g., owing to marriage or birth of a child) and/or the equilibrium is (at least temporarily) disrupted by changes in community fiscal policies. The latter point is of importance in Switzerland, because many communities adjust their fiscal policies to attract certain migrant groups. Yet, despite tax harmonisation efforts at the federal level, the dispersion of tax rates has increased (OECD, 1999B). Our own calculations using data from the Federal Tax Administration show that, on average, between 1995 and 2000 the tax burden at the community level declined, while the standard deviation increased. Therefore, the observed migration in Switzerland cannot simply be attributed a priori to changes in individual preference structures.

\section{Prior empirical studies}

A large and varied body of work exists on the determinants of migration, each study focusing on particular aspects of the migration decision (see Ghatak et al., 1996, for an overview). Likewise, a substantial amount of both theoretical and empirical literature addresses the economic effects of tax competition on individuals and households (see Wilson, 1999, for an overview). Nevertheless, empirical studies on tax competition between governments that focus on differences in income tax rates are still rare, owing primarily to lack of data. Only a few OECD countries have a truly decentralised income tax structure. Among these countries, Switzerland stands out as the country with the largest variation of tax rates at the sub-central level. ${ }^{1}$

The earliest study of tax competition in the Swiss context dates back to Frey (1981), who studied migration in the region of Basle and found no evidence for tax competition. Similarly, Feld (2000), in his analysis of aggregate migration flows among Swiss cantons, finds no evidence for fiscally induced migration at that level. In the related field of public expenditure, Schaltegger (2003) finds no robust evidence for an impact of migration on cantonal public expenditure. Tabin and Keller (2003), in an analysis of whether different social expenditures across the French part of Switzerland induce migration, conclude that family and job-related factors are the prime motives of migration, while social welfare does not seem to affect movement. In contrast, Joumard and Giorno (2002) conclude in their OECD survey on public expenditure in Switzerland that welfare claimants appear to relocate to communities with generous social assistance programmes.

Kirchgässner and Pommerehne (1996), by regressing the shares of income groups across cantons on cantonal tax burdens, industry and infrastructure, find evidence that tax rates have an influence on the distribution of high-income earners across cantons. Furthermore, tax differences seem to be partly capitalised in rents. Feld and Kirchgässner (2001) test Tiebout's club hypothesis in a Swiss context with aggregated data from the 137 largest Swiss communities by regressing the share of various income classes on income tax rates and find evidence for tax competition in Switzerland. However, Schmidheiny (2003) criticises these aggregated approaches for neglecting the inherent endogeneity problem in aggregated data, i.e., because community characteristics are influenced by the choices of the inhabitants, only from the perspective of the individual household can community characteristics be accepted as a given. This endogeneity problem is a strong argument in favour of micro-data analysis. Schmidheiny (2003) circumvents the data problem by

\footnotetext{
${ }^{1}$ However, several countries - including the US - have substantial variation in local property taxes. Thus, a variety of empirical studies are concerned with this kind of tax competition, including Brett and Pinske (2000), Brueckner and Saavedra (2001) and Revelli (2002). The analysis of tax competition via property taxes is, however, fundamentally different (see Mieszkowski and Zodrow, 1989).
} 
focusing on household-level data on migration in the urban agglomeration of Basle in 1997, for which a unique dataset is available. His findings suggest that rich households are significantly more likely than poor households to move to low-tax communities.

To date, however, to our knowledge, no empirical studies on the impact of different income tax rates on migration exist that both employ micro-data and cover large areas. Given that Switzerland alone has sufficient variation in income tax rates to motivate fiscally induced migration, this research void is not surprising. Only with the recently established Swiss Household Panel has a micro-dataset become available that allows for an in-depth and nation-wide analysis of fiscally induced migration.

\section{Institutional background}

Switzerland's tax system reflects the country's federal structure and is unique in several aspects. Of the countries surveyed in OECD (1999A), Switzerland has the highest subcentral government tax share. Only Canada (not surveyed in OECD, 1999A) has a higher share of sub-national government tax receipts. However, in Canada, because income taxes are mainly set at the provincial level, these receipts account for less than $10 \%$ of local government tax revenues (see Joumard and Kongsrud, 2003). In Switzerland (in contrast to other decentralised countries like the US where property taxes are the most prominent local source of revenue), the main local tax sources are personal income taxes. Moreover, Switzerland stands out among OECD countries as the nation in which local governments use their tax-setting autonomy most effectively. ${ }^{1}$ For example, the cantons are largely autonomous in setting their income taxes, both regarding the base and the rates. The local communities can also set their own tax rates within the respective cantonal framework. Admittedly, some harmonisation of cantonal tax structures was achieved in 2000 and 2001; however, this harmonisation covered primarily tax bases and time of taxation. ${ }^{2}$ As a result, for each of the almost 3,000 communities, different tax rates still apply and dispersion is large.

To illustrate this, in the year 2000, for an unmarried individual with no children earning 100,000 Swiss Francs per year, the combined cantonal and local tax burden across Switzerland in communities with more than 2000 inhabitants varied from 8,954 Swiss Francs in Freienbach (Canton Schwyz) to 22,784 Swiss Francs in Le-Chaux-de-Fonds (Canton Neuchâtel). At the top income levels, differences in marginal rates were even more pronounced. Marginal rates at an annual income of 500,000 Swiss Francs ranged from about $21 \%$ (again in Freienbach, Canton Schwyz) to more than $46 \%$ (in Lauterbrunn, Canton Berne). ${ }^{3}$ Even in communities lying less than $20 \mathrm{~km}$ apart, differences in average and marginal effective tax rates of more than $5 \%$ are quite common. This unique situation makes Switzerland a particularly interesting country for analysing the impact of different tax rates on migration. In contrast to internal migration in, for example, the US or the European Union, people may migrate solely for tax reasons and later commute without also having to change employment. In other words, if tax competition matters, it should exhibit a measurable impact in Switzerland.

\footnotetext{
${ }^{1}$ In Nordic countries, local governments also have de jure discretion to set tax rates, but they do not make effective use of this autonomy. Local governments may avoid aggressive tax competition so as not to jeopardise either cooperation in other areas or receipt of vertical government transfers, which often have scope for discretion (Joumard and Kongsrud, 2003).

${ }^{2}$ For a comprehensive overview of the Swiss tax structure and its implications for tax competition, see Waldburger (2003).

${ }^{3}$ These rates include all government levels.
} 


\section{Data and methodology}

Our overall empirical task is to measure the effectiveness of the widely practised taxpolicy measures that communities use to attract new residents. Thus, the focus of our study is to analyse the impact of an individual's tax burden on his or her migration decision.

We conducted this analysis using the first three waves of the Swiss Household Panel (1999-2001), a longitudinal panel survey whose data are gathered annually using CATI (Computer Assisted Telephone Interviewing). For the first wave, a representative sample of 5,074 households from the Swiss population was recruited and a total of 12,931 individuals were interviewed in the autumn of 1999. For 2001, the sample size of the panel was equal to 4,314 households comprising 11,116 individuals. Our analysis is restricted to individuals aged 20 and older.

Two unique features make the Swiss Household Panel particularly interesting for our purposes. First, it is a very rich dataset that includes information on income and taxes and thus provides data on individual tax burdens. ${ }^{1}$ The exact wording of the underlying question is as follows: 'What is the total amount paid yearly by your household in taxes (communal, cantonal, and federal taxes)?'. The panel also contains very rich subjective information, including data on the reasons for migration, which are obviously of particular importance for our analysis. ${ }^{2}$ Second, data are available at the household level, which isaccording to the 'family migration theory' outlined in Section 2-the relevant decisionmaking unit for migration. We define 'migrants' as individuals who change their place of residence (as opposed to locality, which would also include movers within a given community). In the pooled sample, 285 households changed place of residency in either 1998 or 1999. For the sociodemographic characteristics at the individual level, we use the information provided by the individual with the highest personal income-assuming this person to be the most relevant for the migration decision-subsequently referred to as the 'household head'.

Our empirical analysis proceeds as follows. Using data from the 1999 panel, we first present some descriptive information on the features of migrants and compare these with those of non-migrants. In a subsequent step, we use a Cox proportional hazard rate regression model to determine which factors influence the length of stay in the current place of residency. This analysis is possible because the Swiss Household Panel supplies information on the length of stay prior to the movements. The Cox model, a duration analysis that models the probability of an exit (i.e., a move), is based on the following hazard function

$$
\lambda(t) \equiv \mathrm{e}^{\boldsymbol{\beta}^{\prime} \mathrm{x}} \lambda_{0}(t)
$$

where $\lambda_{0}$ depicts the so-called 'baseline' hazard (i.e., the probability of a move) and reflects individual heterogeneity. In principle, would have to be estimated for each observation; however, Cox (1972) has shown that the individual $\beta$ s may be estimated without also explicitly estimating. These estimated $\beta$ s show the effect of a change in an independent variable in $\mathbf{X}$ on the hazard rate (see, e.g., Greene, 1997, pp. 997-9; Wooldridge 2002, pp. 685-91). If the estimated coefficient $\hat{\beta}_{j}$ is greater than zero, a positive relation between the variable $X_{j}$ and the hazard rate exists, i.e., persons with a high value of $X_{j}$ are more inclined

\footnotetext{
${ }^{1}$ Regarding the reliability of income data collected by recall questions, see Bell (1984), Juster and Smith (1997), and Sousa-Poza and Henneberger (2000). See also Cattaneo and Winkelmann (2003), who use the Swiss Household Panel data to study the earnings differentials of German and French speakers in Switzerland

${ }_{2}$ Similar panel datasets from other countries, such as the German Socio-Economic Panel, do not contain a comparable variable.
} 
to migrate and vice versa. Our base Model 1 contains only basic sociodemographic characteristics as explanatory variables, i.e., the number of persons in the household, whether the household has school age children, the age of the household head, his or her employment status and education level and, finally, whether or not the individual concerned is a foreigner. Model 2 adds further sociodemographic variables such as duration of residency, home ownership and external childcare. This latter variable, by indicating whether the household has used (paid) external childcare, shows whether the community provides such facilities. Model 3 expands the basic model with dummies for agglomeration and for the Italian- and French-language regions of Switzerland.

A second set of models includes a tax burden measurement, constructed using the selfreported tax and income data from the questionnaires. Whereas Model 4 uses only the tax burden and household income, Model 5 also adds the sociodemographic variables from Model 1. In a third dataset, we include controls for a variety of variables that correspond to public goods.

An alternative approach is to take tax payments as the dependent variable and analyse whether migration affects these payments. This analysis can be done using a firstdifference estimator. In a two-period case (as applicable here), the first-difference model is equivalent to the traditional fixed-effect model, i.e., it leads to identical estimators and test statistics. However, heteroscedasticity-consistent standard errors can be more easily derived using the first-difference estimator (see Wooldridge 2003, p. 467).

In Switzerland, the tax payment $T_{i}$ depends on six factors-fiscal year, income, marital status, number of children, locality and tax deductions-which can be specified as follows

$$
T_{i t}=\delta_{0} d_{2001}+\boldsymbol{\beta}_{1} \mathrm{X}_{i t}+\alpha_{i}+\varepsilon_{i t}
$$

where $d_{2001}$ is a dummy variable for the year 2001, capturing the general time trend. The variables included in $\mathbf{X}$ are income, marital status and the number of children. With $\alpha_{i}$, we try to capture the unobservable, individual and relatively time-independent factors that affect tax deductions. In the Swiss context, these include mortgage payments and contributions to pension funds within the second and, partly, third pillar. ${ }^{1}$

Thus, the tax rate in the two respective survey periods (1999 and 2001) can be explained as

$$
\begin{gathered}
T_{i 3}=\delta_{0}+\boldsymbol{\beta}_{1} \mathrm{X}_{i 3}+\alpha_{i}+\varepsilon_{i 3} \\
T_{i 1}=\boldsymbol{\beta}_{1} \mathrm{X}_{i 1}+\alpha_{i}+\varepsilon_{i 1}
\end{gathered}
$$

The difference of the two equations leads us to the first-difference equation

$$
T_{i 3}-T_{i 1}=\delta_{0}+\boldsymbol{\beta}_{1}\left(\mathrm{X}_{i 3}-\mathrm{X}_{i 1}\right)+\left(\varepsilon_{i 3}-\varepsilon_{i 1}\right)
$$

which no longer contains the individual, unobserved heterogeneity $\alpha_{i}$. This model now relates differences in the tax payments to changes in the observed characteristics. If a change of locality influences the tax payments, then there should be a correlation between $\left(\varepsilon_{i 3}-\varepsilon_{i 1}\right)$ and past migration between 1999 and 2001.

The first-difference analysis is followed by another set of Cox analyses that focus on other determinants of internal migration. We first run separate duration analyses for employed persons only, to analyse whether job-related issues determine migration. This

\footnotetext{
${ }^{1}$ Switzerland's pension system is based on three pillars. The first pillar is a minimum state pension, the second is based on fully funded occupational benefit plans, and the third is composed of individual retirement savings through contributions that are partly tax deductible (see OECD, 2000, for details).
} 
step is followed by a second set of duration analyses which control for subjective perceptions of various location factors.

The Swiss Household Panel survey for the second and third wave also includes a unique question on the reasons for a change of locality. This item allows identification of the impact of income and other sociodemographic factors on the self-reported reasons for migration. We first classify the reasons into four categories-accommodation-related, personal, locality-related and 'other' reasons for moving - then subsequently run a multinomial logit model that captures the determinants of an individual's migration decision. Even though each respondent can state up to three reasons for migrating, we only consider the prime reasons in the multinomial logit regressions. The analysis is conducted using the pooled sample of the second and third waves. The independent variables include household size, age, education, Swiss citizenship and whether or not the respondent has school-age children. Because, in addition to tax burden, more than 30 migration motives were classified (see the Appendix for the main variable definitions), these data provide a clear picture of the reasons why people migrate and, more importantly, whether this migration is in any way fiscally induced.

\section{Empirical analysis}

In our sample, while 285 households moved in either 1998 or 1999, 3,393 households did not change their place of residency. Thus, we first conduct an analysis of variance between these two groups. The results are presented in Table 1.

In this descriptive analysis, the main predictions of migration theory are confirmed: migrants are significantly younger (meaning that migration is more likely to pay off owing to the larger planning horizon), but home ownership and employment reduce the probability of migration (because of the higher opportunity costs of migration). Furthermore, both employed and unemployed persons are more prone to migrate than nonemployed people (i.e., individuals who are not in the labour force). Finally, the average length of residence for movers is significantly lower than that for non-movers, and foreigners (being less likely to have accumulated location-specific social capital) are more inclined to migrate. Particularly noteworthy is the lack of any significant difference between the groups in either tax burden or gross household income.

To test whether these basic descriptive results hold after other factors are controlled for, we proceed with a series of duration analyses that depict the determinants of migration (see Equation 4). The results are shown in Table 2. Migrants are typically younger than nonmigrants. The probability of migration also declines with increasing household size, i.e., larger households tend to migrate less. As indicated by Equation (1b) above, a migration that would be beneficial from the individual perspective of the household head is not necessarily utility augmenting from the perspective of the entire family (or, more broadly defined, the corresponding household). Thus, migration is less likely to occur in large households, which is confirmed by our data. In addition, foreigners tend to have a significantly higher migration inclination than natives. Even though foreigners' movements may be restricted across Switzerland (see Liebig, 2003), this result indicates that foreigners are quite mobile within cantons. There are two possible explanations for this result. First, the migration decision may be sequential in nature, i.e., foreigners may have only limited information in the beginning, then change their location as soon as the information asymmetries are lower. Second, the attachment to a certain community may be lower, e.g., owing to the lack of family and friendship ties. 
Table 1. Determinants of internal migration-descriptive information

\begin{tabular}{|c|c|c|c|}
\hline & Movers & Stayers & Significance ${ }^{b}$ \\
\hline Tax burden & $0.119(221)$ & $0.131(2541)$ & 0.376 \\
\hline $\begin{array}{l}\text { Annual gross household income } \\
\text { (in Swiss Francs) }\end{array}$ & $90,953(275)$ & $89,998(3093)$ & 0.815 \\
\hline Household size & $2.46(285)$ & $2.85(3393)$ & 0.171 \\
\hline Child of school age ${ }^{a}$ & $0.13(285)$ & $0.13(3393)$ & 0.904 \\
\hline Age & $37.98(285)$ & $47.11(3393)$ & 0.000 \\
\hline Low education ${ }^{a}$ & $0.11(285)$ & 0.17 (3393) & 0.013 \\
\hline High education $^{\mathrm{a}}$ & $0.13(285)$ & $0.12(3393)$ & 0.536 \\
\hline Employment $^{\mathrm{a}}$ & $0.88(285)$ & $0.75(3393)$ & 0.000 \\
\hline Unemployment $^{\mathrm{a}}$ & $0.03(285)$ & $0.01(3393)$ & 0.011 \\
\hline Foreigner $^{\mathrm{a}}$ & $0.17(285)$ & $0.11(3393)$ & 0.002 \\
\hline Duration of residency (years) & $14.12(285)$ & $20.92(3391)$ & 0.000 \\
\hline Home ownership ${ }^{a}$ & $0.14(285)$ & $0.43(3393)$ & 0.000 \\
\hline External childcare $^{a}$ & $0.07(285)$ & $0.04(3393)$ & 0.010 \\
\hline Agglomeration $^{\mathrm{a}}$ & $0.63(285)$ & $0.57(3393)$ & 0.059 \\
\hline Italian language region ${ }^{\mathrm{a}}$ & $0.04(285)$ & $0.04(3393)$ & 0.482 \\
\hline French language region ${ }^{a}$ & $0.32(285)$ & $0.28(3393)$ & 0.124 \\
\hline
\end{tabular}

Note: Number of observations in brackets.

${ }^{a}$ Dummy variables.

${ }^{\mathrm{b}}$ Significance values are based on one-way analyses of variance (one-way ANOVAs).

In addition, home ownership has a significant negative effect, which is not surprising given that home ownership increases the opportunity costs of migration. What may be surprising, however, is that education appears to have no significant impact on the migration decision. However, the signs in our base model correspond to theoretical predictions that time-equivalent migration costs decrease relative to qualification level. ${ }^{1}$ Also worth noting is the significant impact of the employment variable. A priori, one would expect employed people to be less likely to migrate. Yet some of the movements may be job related (see Table 6 below). Moreover, the reference category 'non-employment' is somewhat difficult to interpret, as it encompasses, inter alia, retired and handicapped people-who are less likely to migrate. The net impact of these factors is therefore ambiguous. $^{2}$

In the next step, depicted in Table 3, we include a variable for the individual tax burden. Its coefficient is not significant, and the inclusion of the tax burden does not improve the fit of the model $\left(\chi^{2}=1.572 ; p=0.456\right)$. Thus, these results strongly suggest that there is no relation between migration and tax burden in Switzerland. ${ }^{3}$

The results of our first-difference analysis (Equation 6) confirm this result. They show that - as would be expected-differences in income have a strong and highly significant impact on tax payment (coefficient 0.022; std error 0.006). The number of children has the

\footnotetext{
${ }^{1}$ See Liebig and Sousa-Poza (2004) for a discussion of the impact of qualification on the migration decision.

${ }^{2}$ We also conducted separate analyses for employed individuals with respect to a variety of job-related characteristics. Among these characteristics, only tenure has a significant (negative) impact on duration. The full results are available from the authors upon request.

${ }^{3}$ As an alternative approach, we run a set of logit regressions, with ' 1 ' depicting the people that decided to change their place of residence in 1998 or 1999 and ' 0 ' being the non-movers. The results are qualitatively very similar to those of the Cox regressions. They are available from the authors upon request.
} 
Table 2. Determinants of internal migration-Cox proportional hazard rate model

\begin{tabular}{|c|c|c|c|c|c|c|}
\hline & $\begin{array}{l}\text { Model } 1 \\
\text { coefficient }\end{array}$ & $\begin{array}{l}\text { std } \\
\text { error }\end{array}$ & $\begin{array}{l}\text { Model } 2 \\
\text { coefficient }\end{array}$ & $\begin{array}{l}\text { std } \\
\text { error }\end{array}$ & $\begin{array}{l}\text { Model } 3 \\
\text { coefficient }\end{array}$ & $\begin{array}{l}\text { std } \\
\text { error }\end{array}$ \\
\hline Household size & $-0.162^{\star \star \star}$ & 0.048 & -0.048 & 0.051 & $-0.162^{\star \star \star}$ & 0.049 \\
\hline $\begin{array}{l}\text { Child of school } \\
\text { age }^{\mathrm{a}}\end{array}$ & 0.180 & 0.195 & 0.144 & 0.194 & 0.174 & 0.195 \\
\hline Age & $-0.076^{\star \star \star}$ & 0.006 & $-0.066^{\star \star \star}$ & 0.006 & $-0.076^{\star \star \star}$ & 0.006 \\
\hline Low education ${ }^{\mathrm{a}, \mathrm{b}}$ & -0.237 & 0.192 & -0.263 & 0.193 & -0.236 & 0.192 \\
\hline High education $^{\mathrm{a}, \mathrm{b}}$ & 0.165 & 0.177 & 0.127 & 0.177 & 0.172 & 0.179 \\
\hline Unemployment $^{\mathrm{a}, \mathrm{c}}$ & $0.561^{\star \star}$ & 0.225 & $0.615^{\star \star \star}$ & 0.229 & $0.559^{\star \star}$ & 0.225 \\
\hline Employment $^{\mathrm{a}, \mathrm{c}}$ & $1.523^{\star \star \star}$ & 0.416 & $1.497^{\star \star \star}$ & 0.419 & $1.520^{\star \star \star}$ & 0.416 \\
\hline Foreigner $^{a}$ & $0.400^{\star \star}$ & 0.163 & 0.234 & 0.165 & $0.406^{\star \star}$ & 0.164 \\
\hline Home ownership ${ }^{a}$ & & & $-1.282^{\star \star \star}$ & 0.180 & & \\
\hline External childcare $^{a}$ & & & 0.312 & 0.236 & & \\
\hline Agglomeration $^{\mathrm{a}}$ & & & & & -0.008 & 0.127 \\
\hline $\begin{array}{l}\text { Italian language } \\
\text { region }\end{array}$ & & & & & -0.303 & 0.326 \\
\hline $\begin{array}{l}\text { French language } \\
\text { region }^{\text {a,d }}\end{array}$ & & & & & -0.022 & 0.130 \\
\hline$N$ & 3674 & & 3674 & & 3674 & \\
\hline & $307.81^{\star \star \star}$ & & $362.25^{\star \star \star}$ & & $308.31^{\star \star \star}$ & \\
\hline $\begin{array}{l}P\left[\Delta \chi^{2}\right] \\
\text { (ref.: model 1) }\end{array}$ & & & 0.00 & & 0.81 & \\
\hline
\end{tabular}

Note: Coefficients are exponentiated. Regressions are conducted for individuals older than 20. The explanatory variables reflect the characteristics in the first wave.

${ }^{a}$ Dummy variables.

${ }^{\mathrm{b}}$ Reference category: middle education.

${ }^{\mathrm{c}}$ Reference category: non-employment.

${ }^{\mathrm{d}}$ Reference category: German language region

$\star, \star \star, \star \star \star$ significant at the $10 \%, 5 \%$ and $1 \%$ level, respectively

expected (negative) sign - as children lead to a tax deduction - but owing to the relatively small size of this deduction, it is not significant (-549.2; std error 993.3). The impact of changes in marital status is a priori ambiguous, because-depending on the cantonal tax law-marriage may or may not lead to an increased tax burden for a given household income. Thus, it is not surprising that it has no significant impact either (coefficient 2495.2; std error 2327.4). As there was no substantial overhaul in the tax system in the corresponding period, there was no expectation of a strong time trend, which is also confirmed (coefficient -172.1 ; std error 425.7). However, if changes of residency are indeed tax related, then there should be a correlation between the error terms of the firstdifference equation and past migration. Yet Kendall's tau is equal to 0.063019 and far from significant $(p=0.350304)$. Again, migration seems not to have an impact on the tax burden.

If the tax burden has no significant impact on the migration decision, what else could matter? In an attempt to answer this question, we perform an analysis using alternative explanations of internal migration in Switzerland, again with the Cox proportional hazard rate model. The results are presented in Table 4. Whereas Model 6 only includes basic sociodemographic variables, Model 7 adds subjective, location-related characteristics to the analysis, i.e., living standard satisfaction, noisy environment, problems with pollution and problems with vandalism. These variables correspond to a variety of public goods 
Table 3. Determinants of internal migration including tax burden-Cox proportional hazard rate model

\begin{tabular}{lcccc}
\hline & $\begin{array}{l}\text { Model 4 } \\
\text { coefficient }\end{array}$ & standard error & $\begin{array}{l}\text { Model 5 } \\
\text { coefficient }\end{array}$ & standard error \\
\hline Tax burden & -1.967 & 0.799 & -0.136 & 0.406 \\
Household income $\times 10^{-6}$ & 1.027 & 0.815 & 1.529 & 1.022 \\
Household size & & $-0.134^{\star \star}$ & 0.057 \\
Child of school age & & 0.204 & 0.220 \\
Age & & $-0.086^{\star \star \star}$ & 0.007 \\
Low education & & & -0.082 & 0.220 \\
High education $^{\mathrm{a}, \mathrm{b}}$ & & 0.042 & 0.207 \\
Unemployment $^{\mathrm{a}, \mathrm{c}}$ & & 0.305 & 0.260 \\
Employment $^{\mathrm{a}, \mathrm{c}}$ & & $1.064^{\star \star}$ & 0.514 \\
Foreigner $^{\mathrm{a}}$ & & 0.303 & 0.186 \\
$N$ & 2760 & 2760 & \\
$\chi^{2}$ & 3.64 & $236.366^{\star \star \star}$ & \\
$P\left[\Delta \chi^{2}\right]$ (ref.: model $^{4}$ & & 0.00 & \\
\hline
\end{tabular}

Note: Coefficients are exponentiated. Regressions are conducted for individuals older than 20 . The explanatory variables reflect the characteristics in the first wave.

${ }^{a}$ Dummy variables.

${ }^{\mathrm{b}}$ Reference category: middle education.

${ }^{\mathrm{c}}$ Reference category: non-employment.

${ }^{\mathrm{d}}$ Reference category: German language region.

$\star, \star \star, \star \star \star$ Significant at the $10 \%, 5 \%$ and $1 \%$ level, respectively.

(general quality of life, infrastructure and public safety) and therefore provide an opportunity to control for these factors. ${ }^{1}$ Among these variables, only noise has a significant impact on migration, although the variable on living standard satisfaction is on the margin of significance. Nor does this picture alter when we control for income and tax burden (Model 8). Again, tax burden has no significant impact, even after we control for public goods.

Obviously, neither tax burden nor the perceived characteristics of the location included in Table 4 contribute substantially to explaining migration behaviour in Switzerland. However, the Swiss Household Panel, unlike other panels, also contains information on a total of 32 possible reasons for migrating. In Table 5, we group these reasons into four categories: accommodation-related reasons, personal reasons, locality characteristics and, for the remainder, other reasons.

Table 6 depicts the reasons most often mentioned as the first motive for migration. Although we analyse only migrations involving changes in place of residency (i.e., excluding migrations within a community), accommodation-related factors clearly dominate. More than a quarter of all respondents stated the desire for a larger home; another $11 \%$ aspired to home ownership. This result is in line with a strand of research that emphasises the importance of the housing market on migration (see e.g., Cameron and Muellbauer, 1998; Jones and Hyclak, 1994). However, location-related factors do not figure prominently among the reasons for migration. It should also be noted that no respondent reported taxes as the prime motive for migration.

\footnotetext{
${ }^{1}$ As has been noted in the study by Feld and Kirchgässner (2001, p. 192), inclusion of quality-of-life variables also proxies 'to some extent for housing price differences since these variables would presumably be capitalised into the price of housing.' They thus partly compensate for the lack of housing variables in the model.
} 
Table 4. Public goods, taxes and internal migration - Cox proportional hazard rate model

\begin{tabular}{|c|c|c|c|c|c|c|}
\hline & $\begin{array}{l}\text { Model } 6 \\
\text { coefficient }\end{array}$ & $\begin{array}{l}\text { std } \\
\text { error }\end{array}$ & $\begin{array}{l}\text { Model } 7 \\
\text { coefficient }\end{array}$ & $\begin{array}{l}\text { std } \\
\text { error }\end{array}$ & $\begin{array}{l}\text { Model } 8 \\
\text { coefficient }\end{array}$ & $\begin{array}{l}\text { std } \\
\text { error }\end{array}$ \\
\hline Household size & $-0.164^{\star \star \star}$ & 0.048 & $-0.154^{\star \star \star}$ & 0.048 & $-0.129^{\star \star}$ & 0.057 \\
\hline Child of school age ${ }^{a}$ & 0.254 & 0.194 & 0.227 & 0.194 & 0.218 & 0.220 \\
\hline Age & $-0.080^{\star \star \star}$ & 0.005 & $-0.078^{\star \star \star}$ & 0.005 & $-0.087^{\star \star \star}$ & 0.007 \\
\hline Low education ${ }^{\mathrm{a}, \mathrm{b}}$ & -0.275 & 0.192 & -0.306 & 0.193 & -0.116 & 0.220 \\
\hline High education ${ }^{\mathrm{a}, \mathrm{b}}$ & 0.201 & 0.177 & 0.221 & 0.177 & 0.094 & 0.207 \\
\hline Foreigner $^{\mathrm{a}}$ & $0.406^{\star \star}$ & 0.163 & $0.372^{\star \star}$ & 0.165 & 0.302 & 0.189 \\
\hline $\begin{array}{l}\text { Living standard } \\
\text { satisfaction }\end{array}$ & & & $-0.055^{\star}$ & 0.033 & -0.029 & 0.040 \\
\hline $\begin{array}{l}\text { Noisy } \\
\text { environment }^{\mathrm{a}}\end{array}$ & & & $0.468^{\star \star \star}$ & 0.142 & $0.416^{\star \star \star}$ & 0.162 \\
\hline $\begin{array}{l}\text { Problems with } \\
\text { pollution }^{\text {a }}\end{array}$ & & & -0.121 & 0.176 & -0.190 & 0.204 \\
\hline $\begin{array}{l}\text { Problems with } \\
\text { vandalism }^{\mathrm{a}}\end{array}$ & & & -0.226 & 0.173 & -0.281 & 0.203 \\
\hline Tax burden & & & & & -0.138 & 0.403 \\
\hline $\begin{array}{l}\text { Household } \\
\text { income } \\
\times 10^{-6}\end{array}$ & & & & & $1.776^{\star}$ & 0.988 \\
\hline$N$ & 3674 & & 3664 & & 2754 & \\
\hline $\begin{array}{l}\chi^{2} \\
P\left[\Delta \chi^{2}\right] \text { (reference: } \\
\text { basic model) }\end{array}$ & $299.34^{\star \star \star}$ & & $\begin{array}{c}313.33^{\star \star \star} \\
0.01\end{array}$ & & $239.69^{\star \star \star}$ & \\
\hline
\end{tabular}

Note: Coefficients are exponentiated. Regressions are conducted for individuals older than 20 . The explanatory variables reflect the characteristics in the first wave.

${ }^{\text {a }}$ Dummy variables.

${ }^{\mathrm{b}}$ Reference category: middle education.

$\star, \star \star, \star \star \star$ Significant at the $10 \%, 5 \%$ and $1 \%$ level, respectively.

For a further analysis of the reasons, we ran a multinomial logit with 'other reasons' as the reference category. The results from the pooled regression of the second and third wave (see Table 7) reveal that migration motives are rather randomly distributed among the population, with one notable exception-locality-related characteristics matter more for highly qualified people than for other population groups. Furthermore, migration is significantly more likely to occur because of accommodation-related or personal reasons than for the other two types of reasons.

\section{Conclusions}

The impact of taxation on migration has attracted much interest among economists and policy-makers alike. On the one hand, it is acknowledged that fiscal federalism may be efficiency enhancing in that it allows fiscal policy to adjust to local preferences. As a result, many OECD countries are discussing the issue of tax decentralisation. In Germany, for example, a reform of fiscal federalism currently under discussion aims at providing more taxation autonomy to the Länder. ${ }^{1}$ One important objection against such policies relates to the potential negative spillovers from tax competition among local governments, i.e., local

\footnotetext{
${ }^{1}$ See German Federal Minister of Finance, Hans Eichel, in Frankfurter Allgemeine Zeitung (2003).
} 
Table 5. Classification of migration reasons

\begin{tabular}{ll}
\hline Category & Reason for moving \\
\hline Accommodation & Home too small \\
& Accommodation too expensive \\
& Accommodation too large \\
& Lack of garden/terrace \\
& Aspire to ownership \\
& Change of personal situation \\
& Life event \\
& Inheritance/donation \\
& Change of work/end of studies \\
& Separation/divorce \\
& Problems with neighbours or landlord \\
Personal & Commuting \\
& Desire for countryside \\
& Environment not suited to children \\
& Bad/unpleasant environment \\
Lack of green areas \\
Noise \\
Traffic \\
Air quality \\
Dirty, chaotic area \\
Parking problems \\
Too many foreigners \\
Problems with drugs \\
School quality, image \\
School beginning/change to another school \\
Tax burden \\
Health insurance premiums \\
Problems in administration, politics, society \\
Want more comfort \\
Offer by coincidence \\
Want to change \\
Other \\
\hline
\end{tabular}

governments may engage in wasteful competition for taxpayers that may lead to suboptimally low rates.

However, tax competition will only materialise if actual migration is tax induced. Yet prior empirical studies on the impact of tax competition on migration behaviour have been limited by a lack of comparable data in an international context and a lack of variation in tax rates internally. Only in Switzerland, with a unique tax system in which income taxes are determined primarily at the local level, can the effect of income taxation on migration be adequately studied. Nevertheless, earlier studies on tax competition in Switzerland that have been generally supportive of the notion of tax competition have had to rely on aggregated data associated with inherent endogeneity problems. Therefore, such approaches and models may have been inadequate to the task of analysing individual determinants of migrant location choices. Only with the recent establishment of the Swiss Household Panel has a rich micro-level dataset finally become available for the analysis of taxation's impact on migration behaviour. 
Table 6. The most important migration reasons

\begin{tabular}{lr}
\hline Reason & $\%$ \\
Home too small & 25.9 \\
Change of personal situation & 15.8 \\
Aspire to ownership & 10.9 \\
Want more comfort & 8.1 \\
Other reason & 7.7 \\
Accommodation too expensive & 6.7 \\
Offer by coincidence & 4.3 \\
Change of work/end of studies & 3.8 \\
Separation/divorce & 3.0 \\
Accommodation too large & 2.6 \\
Commuting & 2.2 \\
\hline
\end{tabular}

Table 7. Determinants of internal migration-multinomial logit

\begin{tabular}{lcccccc}
\hline & $\begin{array}{l}\text { Accommodation } \\
\text { coefficient }\end{array}$ & std error & $\begin{array}{l}\text { Personal } \\
\text { coefficient }\end{array}$ & std error & $\begin{array}{l}\text { Locality } \\
\text { coefficient }\end{array}$ & std error \\
\hline Constant & $0.949^{\star}$ & 0.488 & $1.152^{\star \star}$ & 0.550 & 0.300 & 0.927 \\
Household size & 0.072 & 0.093 & -0.181 & 0.115 & -0.286 & 0.208 \\
Child of school & -0.130 & 0.379 & -0.084 & 0.466 & 1.032 & 0.663 \\
age $^{\mathrm{a}}$ & & & & & & \\
Age $_{\text {Low education }}^{\text {a,b }}$ & -0.006 & 0.011 & -0.015 & 0.012 & -0.033 & 0.023 \\
High education $^{\mathrm{a}, \mathrm{b}}$ & -0.355 & 0.374 & 0.099 & 0.417 & -0.331 & 0.817 \\
Foreigner $^{\mathrm{a}}$ & 0.382 & 0.390 & 0.609 & 0.433 & $1.143^{\star}$ & 0.604 \\
$N$ & 0.008 & 0.325 & -0.636 & 0.416 & -0.944 & 0.799 \\
${\text { Pseudo- } R^{2}}^{2}$ & 447 & & & & & \\
$\chi^{2}$ & $0.064^{\mathrm{c}}$ & & & & & \\
\hline
\end{tabular}

Note: Regressions are conducted for individuals older than 20. The explanatory variables reflect the characteristics prior to the move. The reference category is 'other reasons'.

${ }^{\text {a }}$ Dummy variables.

${ }^{\mathrm{b}}$ Reference category: middle education.

${ }^{\mathrm{c}}$ The pseudo- $R^{2}$ measure is that of Nagelkerke (1991).

$\star, \star \star, \star \star \star$ significant at the $10 \%, 5 \%, 1 \%$ level, respectively.

The most important conclusion of our analysis is that tax rates clearly have no significant impact on the migration decision. Nevertheless, the fact that few, if any, migrants are driven by tax considerations does not rule out a tax burden influence over the migration choices of some very high earners. Indeed, some such prominent cases have recently received much public attention. ${ }^{1}$ Yet our analysis suggests that these cases are the exception. Furthermore, these legal translocations seldom involve a physical migration and are therefore beyond the focus of our study. Thus, large-scale, tax-induced migration seems highly unlikely, even in the Swiss context in which such relocation would be possible without a job change. Rather, our results point to the importance of the housing market in migration decisions. That is, most migration within Switzerland appears related to the

\footnotetext{
${ }^{1}$ The perhaps most prominent examples are the German sportsmen Michael Schumacher and Jan Ulrich, both of whom moved to Switzerland.
} 
housing market, which may be explained by the relatively low home-ownership rates in Switzerland.

To what degree can the results of our national study be broadened to the general issue of tax competition? As a highly federalist country with three languages, migration barriers in Switzerland should be higher than in unitary countries with only one official language. However, because Switzerland is a very small country, commuting across linguistic zones is not a problem of distance. What remains unclear is the effect of the high per capita income in Switzerland on the inclination to engage in tax-induced migration. On the one hand, a higher income increases the monetary value of each percentage point of tax rate difference. On the other, the high income level in Switzerland has resulted in a very high living standard by international comparison, which might reduce the overall inclination to migrate for tax savings.

All things considered, it can be concluded that, if tax competition is virtually absent in a country with a decentralised tax structure, it should not have a great impact on international migration - at least as far as migration across linguistic zones is concerned. Therefore, it seems improbable that disparities in tax rates, such as those within the European Union, will have a large impact on international migration. This finding also casts some doubts on recent policies in various OECD countries that aim to attract certain migrant groups (e.g., highly skilled migrants) through tax incentives.

\section{Bibliography}

Altshuler, R. and Goodspeed, T. 2002. 'Follow the Leader? Evidence on European and U.S. Tax Competition', Department Working Paper No. 200226, Rutgers University, Department of Economics

Bell, R. 1984. Item nonresponse in telephone surveys: an analysis of who fails to report income, Social Science Quarterly, vol. 65, 207-15

Brett, C. and Pinske, J. 2000. The determinants of municipal tax rates in British Columbia, Canadian fournal of Economics, vol. 33, 695-714

Brueckner, J. 2004. Fiscal decentralisation with distortionary taxation: Tiebout vs. tax competition, International Tax and Public Finance, vol. 11, 133-53

Brueckner, J. and Saavedra, L. 2001. Do local governments engage in strategic property-tax competition?, National Tax fournal, vol. 54, 203-29

Cameron, G. and Muellbauer, J. 1998. The housing market and regional commuting and migration choices, Scottish Fournal of Political Economy, vol. 45, 420-46

Cattaneo, A. and Winkelmann, R. 2003. 'Earnings Differentials between German and French Speakers in Switzerland', Working Paper No. 309, Socioeconomic Institute, University of Zurich

Cox, D. 1972. Regression models and life tables, Fournal of the Royal Statistical Society, Series B, vol. $34,187-220$

Dowding, K. and John, P. 1994. Tiebout: a survey of the empirical literature, Urban Studies, vol. $31,767-97$

Feld, L. 2000. Steuerwettbewerb und seine Auswirkungen auf Allokation und Distribution: ein Überblick und eine empirische. Analyse für die Schweiz, Tübingen, Mohr Siebeck

Feld, L. and Kirchgässner, G. 2001. Income tax competition at the state and local level in Switzerland, Regional Science and Urban Economics, vol. 31, 181-213

Frey, R. 1981. Bestimmungsfaktoren der inter- und intraregionalen Wanderungen-Eine ökonometrische Untersuchung für die Schweiz und die Region Basel, pp. 13-52 in Frey, R. (ed.), Von der Land- zur Stadtflucht: Bestimmungsfaktoren der Bevölkerungs-wanderungen in der Region Basel, Bern/Frankfurt, Peter Lang

Frankfurter Allgemeine Zeitung. 2003. Eichel sieht Finanzverbund als Reformbremse, Frankfurter Allgemeine Zeitung, 17 November, 11 
Ghatak, S., Levine, P. and Price, S. 1996. Migration theories and evidence: an assessment, fournal of Economic Surveys, vol. 10, no. 2, 159-98

Greene, W. 1997. Econometric Analysis, Upper Saddle River, N.J., Prentice Hall

Hansen, N. and Kessler, A. 2001. (Non-)existence of equilibria in multicommunity models, fournal of Urban Economics, vol. 50, 418-35

Harris, J. and Todaro, M. 1970. Migration, unemployment and development: a two-sector analysis, American Economic Review, vol. 60, 126-42

Hicks, J. 1932. The Theory of Wages, New York, Macmillan

Jones, G. and Hyclak, T. 1994. Housing price, migration and regional labor markets, fournal of Housing Economics, vol. 3, 312-29

Joumard, I. and Giorno, C. 2002. 'Enhancing the Effectiveness of Public Spending in Switzerland', OECD Economics Department Working Paper No. 332

Joumard, I. and Konsgrud, P. 2003. 'Fiscal Relations across Government Levels', OECD Economics Department Working Paper No. 375

Juster, F. and Smith, J. 1997. Improving the quality of economic data: lessons from the HRS and AHEAD, fournal of the American Statistical Association, vol. 92, 1268-78

Kirchgässner, G. and Pommerehne, W. 1996. Tax harmonization and tax competition in the European Union: lessons from Switzerland, fournal of Public Economics, vol. 60, 351-71

Liebig, T. 2003. Recruitment of foreign labour in Germany and Switzerland, in OECD (ed.), Migration for Employment-Bilateral Agreements at a Crossroads, Paris, OECD

Liebig, T. and Sousa-Poza, A. 2004. Migration, self-selection and income inequality: an international analysis, Kyklos, vol. 57, 125-46

Massey, D., Arango, J., Hugo, G., Kouaouci, A., Pellegrino, A. and Taylor, E. 1993. Theories of international migration: a review and appraisal, Population and Development Review, vol. 19, no. 3, 431-66

Mieszowski, P. and Zodrow, G. 1989. Taxation and the Tiebout model: the differential effects of head taxes, taxes on land rents, and property taxes. Fournal of Economic Literature, vol. 27, 1098-146

Mincer, J. 1978. Family migration decisions, fournal of Political Economy, vol. 86, 749-73

Nagelkerke, N. 1991. A note on the general definition of the coefficient of determination, Biometrika, vol. 78, no. 3, 691-92

Oates, W. 1969. The effects of property taxes and local public spending on property values: an empirical study of tax capitalisation and the Tiebout hypothesis, fournal of Political Economy, vol. $77,951-71$

Oates, W. 1972. Fiscal Federalism, New York, Harcourt Brace Jovanovich

OECD 1999A. Taxing Powers of State and Local Government, OECD Tax Policy Studies No. 1, Paris, OECD

OECD 1999B. Economic Survey of Switzerland, Paris, OECD

OECD 2000. Economic Survey of Switzerland, Paris, OECD

Revelli, F. 2002. Testing the taxmimicking versus expenditure spill-over hypotheses using English data, Applied Economics, vol. 4, 1723-31

Schaltegger, C. 2003. Fiskalischer Föderalismus und Staatstätigkeit, Zeitschrift für Wirtschaftspolitik, vol. 52, 84-110

Schmidheiny, K. 2003. 'Income Segregation and Local Progressive Taxation: Empirical Evidence from Switzerland', HWWA Discussion Paper No. 248, Hamburg

Sjaastad, L. 1962. The costs and returns of human migration, fournal of Political Economy, vol. 70 (Suppl.), 80-93

Sousa-Poza, A. and Henneberger, F. 2000. Wage data collected by telephone interviews: an empirical analysis of the item nonresponse problem and its implications for the estimation of wage functions, Swiss fournal of Economics and Statistics, vol. 136, 79-98

Tabin, J. and Keller, V. 2003. Le tourisme social existe-t-il?, Lausanne, Haute École Spécialisé

Tiebout, C. 1956. A pure theory of local expenditures, fournal of Political Economy, vol. 64, 416-24

Todaro, M. 1969. A model of labor migration and urban unemployment in less developed countries, American Economic Review, vol. 59, 138-48

Waldburger, R. 2003. National report: Switzerland, in Schön, W. (ed.), Tax Competition in Europe, Amsterdam, International Bureau of Fiscal Documentation 
Wallace, S. and Edwards, B. 1999. Personal income tax, pp. 149-90 in Hildreth, W. and Richardson, J. (eds), Handbook on Taxation, New York/Basel, Dekker

Wallace, S., DeLorme, C. and Kamerschen, D. 1997. Migration as a consumption activity, International Migration, vol. 5, 37-58

Wilson, J. 1999. Theories of tax competition. National Tax fournal, vol. 52, 269-304

Wooldridge, J. 2002. Econometric Analysis of Cross Section and Panel Data, Cambridge, MA/ London, MIT Press

Wooldridge, J. 2003. Introductory Econometrics, Mason, OH, Thomson South-Western

\section{Appendix}

Table A1. Definitions of selected variables and terms used in the analysis

Variable/term Definition

Tax burden

Household head

Low education

High education

Household size

Child of school age

Foreigner

Job satisfaction

Living standard satisfaction

Noisy environment

Problems with pollution

Problems with vandalism

External childcare

Agglomeration

Italian language region

French language region
Annual tax payments divided by household income. Prior to 2001, tax assessment lags two years behind, i.e., reported tax payments in 1999 are based on the income in 1997.

Person above 20 earning the highest income in the household. If this maximum income is reported by more than one person in the household, the oldest respondent among these was chosen.

Equal to 1 if respondent has less than an apprenticeship or A-level; 0 otherwise

Equal to 1 if respondent has a university degree; 0 otherwise Number of individuals living in the household

Equal to 1 if a child under the age of 16 is living in the household; 0 otherwise

Equal to 1 if respondent does not have a Swiss nationality; 0 otherwise

Measures the overall job satisfaction on a scale from 0 ("not at all satisfied') to 10 ('completely satisfied')

Measures the overall satisfaction with the standard of living on a scale from 0 ('not at all satisfied') to 10 ('completely satisfied')

Equal to 1 if respondent perceived problems with noisy external environment; 0 otherwise

Equal to 1 if respondent perceived problems with pollution, environment, linked to traffic or presence of industry; 0 otherwise

Equal to 1 if respondent perceived problems with vandalism in the neighbourhood; 0 otherwise

Equal to 1 if respondent received regular external help for childcare; 0 otherwise

Equal to 1 if respondent resides in a centre or suburban community; 0 otherwise

Equal to 1 if respondent resides in the Canton of Ticino; 0 otherwise

Equal to 1 if respondent resides in the Cantons of Fribourg, Geneva, Jura, Neuchâtel, Valais or Vaud; 0 otherwise 